\title{
Evaluation of Vetiver Grass (Vetiver zizanodes) Potential to Soil Erosion Control at Assosa, Benishangul Gumuz, Ethiopia
}

\author{
Obsa Adugna*, Dereje Alemu and Tesfahun Melkamu \\ Ethiopian Institute of Agricultural Research, Ethiopia
}

Submission: December 15, 2018; Published: January 11, 2019

*Corresponding author: Obsa Adugna, Ethiopian Institute of Agricultural Research, Ethiopia

\begin{abstract}
Vetiver occurs in many countries throughout the world and used as biological soil and water conservation measure. It is introduced to Ethiopia in the 1960's. this experiment was initiated with the aim of evaluating the soil conservation potential of vetiver grass hedges in Benishangul gumuz region of Assosa zone (Assosa district of Komeshiga-28 for two consecutive research years (2013/14-2014/15) on farm land. The site was selected purposively based on the its slope and severity to soil erosion. Biophysical of the experiment and socio -economic data is of participant farmers were collected to evaluate the impact of the study. The potential of vetiver grass to conserve the soil were evaluated by using the pins installed at the upper, middle and lower part of the hedgerows to determine the rate of soil erosion and deposition. A total of $17 \mathrm{HHs}$ were sampled to assess the perception, acceptance and adoption level of the farmers using simple random sampling technique. The result indicated the pin height reduction from the initial height of $35 \mathrm{~cm}$ by the mean value of $8 \mathrm{~cm}, 6 \mathrm{~cm}$ and $5.3 \mathrm{~cm}$ for the pin installed at the upper, middle and lower part of the hedge rows within two consecutive research year. $94.1 \%$ of the respondents also indicated the presence and severity of soil erosion on their farm land which is increasing from time to time in alarming rate and where all of the farmers mentioned loss of fertile top soil and in turn yield reduction as the problem. All (100\%) of the farmers were confident enough to reduce soil erosion on their farm land using vetiver grass and all of the farmers ratified the effectiveness of the measures to reduce soil erosion and willing to use vetiver grass on their farm land thereby to disseminate the technology to (other) non- participant farmers.
\end{abstract}

Keywords: Vetiver; Soil loss; Pin height; Soil erosion

Abbrevations: EIAR: Ethiopian Institute of Agricultural Research; ASARC: Assosa Agricultural Research Center; BGRS: Benishangul-Gumuz Regional State; VI: Vertical Interval; SPSS: Statistical Package for Social Sciences; VGT: Vetiver Grass Technologies

\section{Introduction}

Land degradation, comprising degradation of the natural vegetation cover, soil erosion, loss of soil fertility and moisture stress is a well-known problem in Ethiopian highlands [1]. Land degradation, particularly by water erosion, is an important factor in both the long-term decline and the seasonal reduction in food crop production [2]. Soil erosion in Ethiopian Highlands degrades the soil resources on which agricultural production are based [3-4]. This threat stems from the depletion and degradation of the vegetation cover of the country, especially forests, and exploitative farming practices. The detachment of soil particles from the landmass and the transportation of the loosened material to another place, termed soil erosion Elision 1946; Hudson 1965 is perhaps the most fearsome threat confronting mankind today [5]. Being a limited and an irreplaceable resource, soil erosion poses a great danger to agricultural production. Though the magnitude varies with ecological zones owing to variations in the interplay of causative factors, soil erosion persists severely, on agricultural lands in Nigeria. It continues to pose a formidable threat to both national food security and environmental quality. To curb erosive land degradation requires soil conservation measures that are cheap, replicable and Sustainable. The use of vetiver grass has offered such prospects in a wide range of climatic environments 283 [6]. Though the grass grows in Nigeria, its potential for soil and water conservation has not been realized [7], let alone quantified.

Recently, EIAR (Ethiopian Institute of Agricultural Research) financed soil and water management and/or conservation research has been initiated by [8] and in this work an endeavor has been made to identify and characterize indigenous soil and water conservation materials and practices in the Metekel zone of Benishangul Gumuz with the aim of making recommendations based on the research findings and launching further research 
interventions. In the assessment, it has been found out that farmers in the area have various agronomic practices like (shenna, intercropping, crop rotation); and vegetative materials (Nechsar, Dagalla, kolla sembelet and others) used for soil and water conservation and gully rehabilitation, which could further be improved and/or augmented with other practices for gully rehabilitation (brush wood check dams) and materials for soil conservation on farm lands such as Vetiver grass (Vetiver zizanoides) hedges. Vetiver occurs in many countries throughout the world. It is introduced to Ethiopia in the 1960's. Vetiver is not site specific, it grows in a wide variety of soils and climatic conditions, it is easy to establish, it is not time consuming, a larger kilometer can be established within a season, very effective and cheaper, it can with stand livestock browsing and trampling. It is promoted as a strategic soil conservation measure in some parts of the country in an effort to halt soil erosion and land degradation [9]. The grass is used for rehabilitation of gullies, road cuts and drains stabilization, river bank protection, watershed rehabilitation for dam side protection, forage, wet land protection, and income generation for Schools [10]. Therefore, this study was initiated with the aim of enhancing the awareness of the farming communities and evaluating the soil conservation potential of vetiver grass hedges at Assosa, Benishangul Gumuz.

\section{Objective of the study}

a) To evaluate the potential of vetiver grass on soil and water conservation.

b) To create awareness among the farmers on biological soil and water conservation measures.

\section{Material and Method}

\section{Description of the study area}

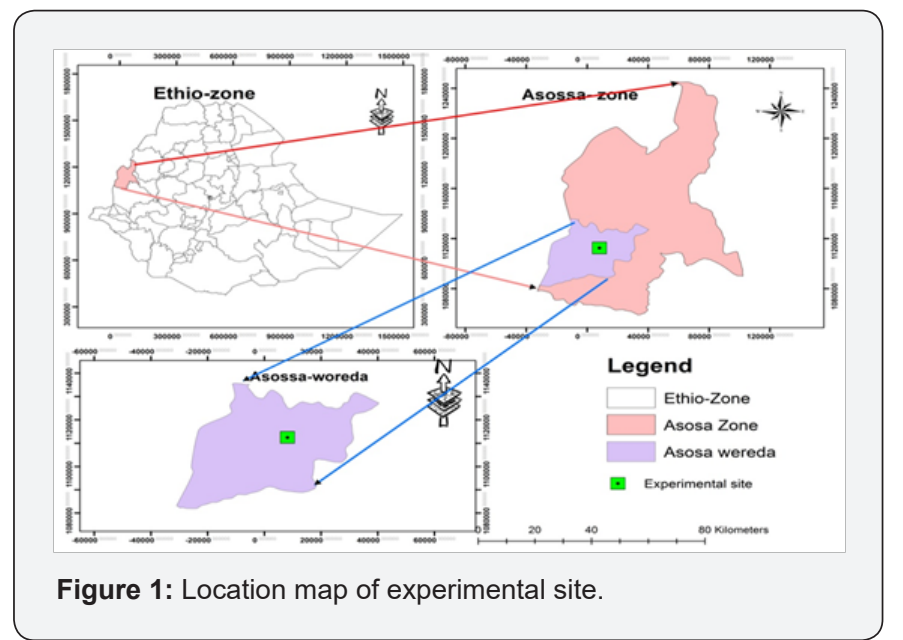

The study was conducted at the Assosa Agricultural Research Center (ASARC), which is located in Assosa District at Benishangul-Gumuz Regional State (BGRS). The ASARC is located in the western part of Ethiopia from $10^{\circ} 01^{\prime} 25^{\prime \prime}$ to $10^{\circ} 02^{\prime} 50^{\prime \prime}$ north latitude and from $34^{\circ} 33^{\prime} 50^{\prime \prime}$ to $34^{\circ} 34^{\prime} 35^{\prime \prime}$ east longitude. The study area covers a total land area of 202.5 ha with geology of Tarmabe basalt, sometimes porphyritic of the Miocene to Pliocene period Tefera et al. 1996. The Assosa District is characterized by hot to warm moist lowland plain with uni-modal rainfall pattern. The rainy season starts at the early May and lasts at the end of October with maximum rainfall in the months of June, July, and August. The total annual average (2000-2007) rainfall is $1316 \mathrm{~mm}$. The annual mean minimum and mean maximum temperatures of the District for the periods from 2000 to 2008 were 16.75 and $27.92{ }^{\circ} \mathrm{C}$, respectively. The soil type of the study area was characterized as Nitisol (Figure 1).

\section{Methodology}

The study area was selected purposively with different stakeholders (Farmers, kebele administration, DAs and wereda natural resource experts) based on prevalence of soil erosion problem and accessibility as criteria for site selection. An area of land with a slope $>5 \%$ was selected and a group of farmers which has 10-15 members were established to handle the Vetiver grass experiment. Training on the uses, propagation and planting of the biological materials as well as the management of the hedges on farmlands were also provided to participant farmers and DAs prior to the establishment of the Vetiver experiments.The vertical interval (VI) used was 1 meter since the slope of the study area was $8 \%$. The Horizontal Interval (HI) were calculated as:

$$
H I=\frac{V I}{S} \times 100
$$

Where: HI is horizontal interval in meter.

VI is vertical interval in meter.

$\mathrm{S}$ is land slope in percentage.

A total of 2-3 tillers of the Vetiver grass were planted along the contours in double rows with staggered pattern. The inter and intra-row spacing was $20 \mathrm{~cm}$. A-Frame (contour mapping), Clinometer (Slope determination), Pins (soil erosion depth monitoring), plastic string, meters, Machete, Reck, and Vetiver grasses were used.

\section{Pin installation and its data collection}

Double pins were planted firmly between the hedges to monitor erosion and deposition of soil particles. The pins were erected at three points, $50 \mathrm{~cm}$ away from the hedges on both sides and at the middle. The pin heights were measured every month during the cropping season. Increase in pin height was considered as soil removal while a decrease of the height was considered as deposition.

\section{Household survey}

Socioeconomic status of the participant farmers such as gender, wealth, age, education, perception of land degradation 
and mitigation solutions were collected through structured questioner.

\section{Soil sampling}

Composite soil samples from two depth (0-15 and 1530) were collected before establishing the grass hedges. Replicated soil samples from the upper, middle and lower parts of the hedgerows were collected at the end of the experiment for soil $\mathrm{pH}$, organic $\mathrm{C}$, total $\mathrm{N}$, available $\mathrm{P}$ and exchangeable $\mathrm{K}$ determination.

\section{Soil sample preparation}

Prior to the analysis, the soil samples collected from different depths were air dried, ground and sieved to pass through $2 \mathrm{~mm}$ size sieve in preparation for laboratory analysis of most soil physical and chemical properties. The soil samples were further sieved to pass through a $0.5 \mathrm{~mm}$ size sieve for the analysis of total nitrogen.

\section{Analysis of soil chemical properties}

The $\mathrm{pH}$ of the soil was measured potentiometrically using a digital $\mathrm{pH}$ meter in the supernatant suspension of $1: 2.5$ soil to water ratio. Organic carbon was determined following the Walkley-Black wet digestion method as described by Ranst et al. 1999 whereas the Kjeldahl procedure was followed for the determination of total nitrogen as described by Ranst et al. 1999. Available phosphorus was determined by the Olsen procedure. In the Olsen procedure, the soil samples were shaken with $0.5 \mathrm{M}$ sodium bicarbonate at nearly constant $\mathrm{pH}$ of $8.5 \mathrm{in}$ 1:20 of soil to solution ratio for half an hour and the extracts were obtained by filtering the suspension Olsen et al. 1954 [11-13].

\section{Statistical analysis}

The collected raw data were systematically coded and analyzed using descriptive statistics using Statistical Package for Social Sciences (SPSS) version 20.0 for the household survey and presented with the help of series of tables and figures.

\section{Result and Discussion}

\section{Rainfall distribution}

(Figure 2) The amount and distribution of precipitation that causes runoff varied during this 2 -year study. Table 1 shows the monthly distribution of rainfall at the experimental sites. At the season, annual rainfall that causes runoff in 2013 and 2014 was 1161.8 , and $877.8 \mathrm{~mm}$ respectively.

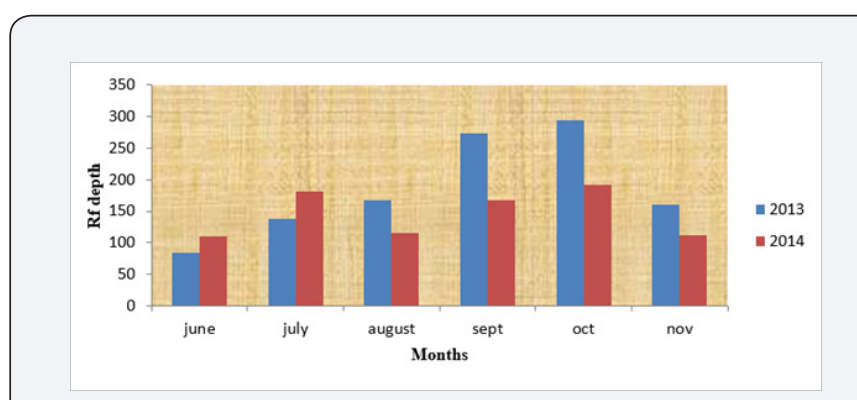

Figure 2: Rainfall distribution at the experimental site.

\section{Biophysical Data}

\section{Erosion and deposition data}

The pins height was measured and recorded every month at the growing season of crops (Figure 3).

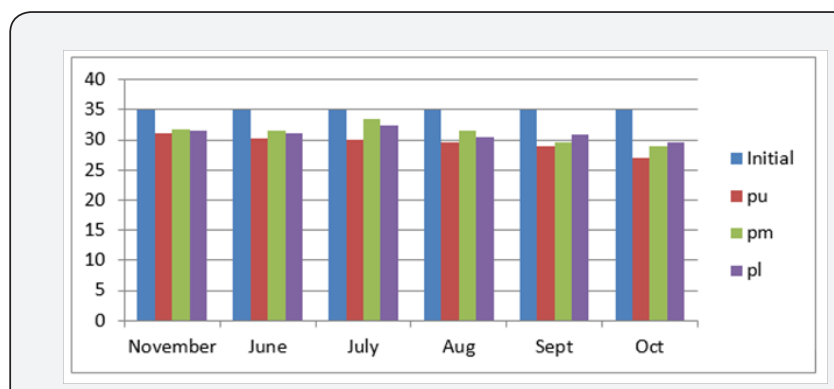

Figure 3: Summary of the average monthly pin height for Vetiver at komeshiga-28.

$\mathrm{Nb}$ : the above data is in $\mathrm{cm}$.

Where, $\mathrm{Pu}=$ pin installed at $50 \mathrm{~cm}$ from hedges upper of the hedges.

$\mathrm{Pm}=$ pin installed at middle of the hedges.

$\mathrm{Pl}=$ pin installed at lower of the hedges (at $50 \mathrm{~cm}$ from hedges).

The Pins height were decreased by mean value of $4 \mathrm{~cm}$, $2.75 \mathrm{~cm}$ and $1.8 \mathrm{~cm}$ for the pin installed at the upper, middle and lower part of the hedge grows respectively as compared to its initial height on the second year and decreased by mean value of $8 \mathrm{~cm}, 6 \mathrm{~cm}$ and $5.3 \mathrm{~cm}$ for the pin installed at the upper, middle and lower part of the hedge rows from its starting which shows the great potential of vetiver grass on reducing soil erosion (Table 1).

Table 1: Soil chemical properties at Komeshiga-28 before and after 2005/06 rainy season.

\begin{tabular}{|c|c|c|c|c|c|c|c|c|c|c|c|c|}
\hline & \multicolumn{4}{|c|}{ Before (2005/06) } & \multicolumn{3}{c|}{ After (2006/07) } \\
\hline Parameters & \multicolumn{3}{|c|}{$\mathbf{0 - 1 5}$} & \multicolumn{3}{|c|}{$\mathbf{1 5}-30$} & \multicolumn{3}{|c|}{$\mathbf{0 - 1 5}$} & 15-30 \\
\hline & Pu & PM & PL & Pu & PM & PL & Pu & PM & PL & Pu & PM & PL \\
\hline PH & 5.97 & 5.82 & 5.73 & 5.73 & 5.79 & 5.81 & 5.37 & 5.09 & 5.34 & 5.16 & 5.44 & 5.16 \\
\hline OC & 2.92 & 3.08 & 2.9 & 2.4 & 2.8 & 2.8 & 1.83 & 2.1 & 1.8 & 1.86 & 1.86 & 1.77 \\
\hline
\end{tabular}




\section{International Journal of Environmental Sciences \& Natural Resources}

\begin{tabular}{|c|c|c|c|c|c|c|c|c|c|c|c|c|}
\hline $\mathrm{N}$ & 0.19 & 0.18 & 0.15 & 0.15 & 0.2 & 0.2 & 0.16 & 0.13 & 0.16 & 0.12 & 0.17 & 0.18 \\
\hline $\mathrm{P}$ & 4.45 & 4.32 & 3.81 & 2.54 & 3.96 & 2 & 18.7 & 24.9 & 18.7 & 31 & 6.2 & 46.6 \\
\hline $\mathrm{K}$ & 0.05 & 0.1 & 0.13 & 0.13 & 0.09 & 0.091 & 0.16 & 0.32 & 0.37 & 0.18 & 0.16 & 0.11 \\
\hline $\mathrm{CEC}$ & 4.4 & 19.8 & 20.9 & 10.8 & 8.2 & 12.4 & 16.2 & 21 & 18 & 18.8 & 15.8 & 15.2 \\
\hline
\end{tabular}

\section{Soil physic-chemical properties}

Soil sample were collected from two depths of the soil $0-15 \mathrm{~cm}$ and $15-30 \mathrm{~cm}$, to evaluate the effect of biological measures of soil and water conservation on soil fertility improvement and soil loss. As the above table shows, there was reduction of $\mathrm{Ph}, \mathrm{OC}, \mathrm{N}$, $\mathrm{P}$ and $\mathrm{k}$ at both depths except CEC which shows the continuous effect of soil erosion on soil fertility reduction .It is known that vetiver is used to conserve the soil which comes from two consecutive hedge rows rather than increasing the fertility status of original soil. This reduction shows that, the soil eroded and deposited in front of the hedge is poor in nutrient content than that of original soil particle because of removal of the top soil layer/fertile soil which is rich in organic carbon content by water erosion.

\section{Socio-economic characteristics of the sampled households}

\section{Sex, age and educational status}

The total of participant farmers in the study were 27 households (Komeshiga-28) and 17 households (selga-19) were selected to generate qualitative data of farmers' perception on potential of vetiver grass on soil and water conservation by comprising $94.1 \%$ male and $5.1 \%$ female. The educational status of the farmer is the key factor for good understanding of their environment and by considering this, education level of the participant farmers was collected. As the study reveals, $52.9 \%$ were illiterate where as $47.1 \%$ of the farmers have attended their primary education. As the below chart shows, most of the participant farmers were non-educated which may affect the awareness of the community on soil erosion and its effect.

Perception, acceptance and adoption of the farmers on vetiver grass

\section{Farmers perception on soil erosion}

(Table $2 \& 3$ ) The participant farmers were interviewed with the aim of assessing the perception of farmers on presence of soil erosion, severity, erosion type, effect and its rate of change over time on their agricultural land. Based on this, $94.1 \%$ of the farmers were mentioned that the presence of soil erosion problem on their agricultural land where as the left $5.9 \%$ were not aware of the problem. All the farmers (100\%) are confident that the problem of soil erosion can be reduced by using different soil and water conservation technologies. Most of the farmers were not ever discussed, know, and participated on demonstration of soil and water conservation before. As indicated above on the table, $47.1 \%, 29.4 \%$ and $23.5 \%$ were affected by rill, sheet and gully erosion respectively. But, the rate of soil erosion is increasing over time and affecting the farmers by eroding the fertile top soil there by reducing the productivity.

Table 2: Farmer's perception on soil erosion.

\begin{tabular}{|c|c|c|c|}
\hline \multirow{2}{*}{ No. } & \multirow{2}{*}{$\begin{array}{l}\text { Question for Perception Evalu- } \\
\text { ation }\end{array}$} & \multicolumn{2}{|c|}{ Answer of Respondents (\%) } \\
\hline & & Yes & No \\
\hline 1 & $\begin{array}{l}\text { Problem of soil erosion on their } \\
\text { farm land }\end{array}$ & 94.1 & 5.9 \\
\hline 2 & Can soil erosion be reduced & 100 & \\
\hline 3 & $\begin{array}{c}\text { Have you ever discussed and draw } \\
\text { potential solution for soil erosion } \\
\text { problem of your area }\end{array}$ & 52.9 & 47.1 \\
\hline 4 & $\begin{array}{l}\text { Do you know about SWC technolo- } \\
\text { gies before }\end{array}$ & 64.7 & 35.3 \\
\hline 5 & $\begin{array}{l}\text { Have you ever participated on } \\
\text { demonstration and field days of } \\
\text { SWC technologies before }\end{array}$ & 11.8 & 88.2 \\
\hline
\end{tabular}

Table 3: Farmer's perception on soil erosion.

\begin{tabular}{|c|c|c|}
\hline No & Perception Parameters & Respondents (\%) \\
\hline 1 & Severity of soil erosion on their farm land & 47.1 \\
\hline & Severe & 52.9 \\
\hline
\end{tabular}




\section{International Journal of Environmental Sciences \& Natural Resources}

\begin{tabular}{|l|c|c|}
\hline 2 & Water erosion type on their farmland & 29.4 \\
\hline & Sheet & 47.1 \\
\hline & Rill & 23.5 \\
\hline & Gully & 94.1 \\
\hline & Soil erosion change over time & 5.9 \\
\hline & Highest & 100 \\
\hline & Medium & 100 \\
\hline
\end{tabular}

Indicators of farmers acceptance of vetiver grass technologies (VGT)

Table 4: Farmer's acceptance of VGT.

\begin{tabular}{|c|c|c|c|}
\hline \multirow{2}{*}{ No. } & $\begin{array}{c}\text { Questions for Acceptance Eval- } \\
\text { uation }\end{array}$ & Answer of Respondents (\%) & Yes \\
\cline { 3 - 4 } & $\begin{array}{c}\text { Did you know the vetiver grass } \\
\text { before }\end{array}$ & 29.4 & 70.6 \\
\hline 2 & $\begin{array}{c}\text { Is vetiver grass being effective in } \\
\text { arresting soil erosion }\end{array}$ & 100 & 5.9 \\
\hline 3 & $\begin{array}{c}\text { Do you believe that vetiver grass } \\
\text { has the potential to improve land } \\
\text { productivity }\end{array}$ & 94.1 & 5 \\
\hline
\end{tabular}

(Table 4) The acceptance of vetiver grass by the farmers and its potential on soil and water conservation has also been assessed. 70.6\% of the participant farmers didn't know vetiver grass and its potential before introduction of the technology where only $29.4 \%$ of them have its slight information. After introduction, all of the farmers have ratified the effectiveness of the grass on arresting soil erosion and $94.1 \%$ of the farmers believe that the productivity of their farm land will be improved by using vetiver.

Indicators of farmer's adoption of vetiver grass technologies (VGT)

Table 5: Farmer's adoption of VGT.

\begin{tabular}{|c|c|c|c|}
\hline \multirow{2}{*}{ No. } & $\begin{array}{c}\text { Questions for Adoption Evalu- } \\
\text { ation }\end{array}$ & Answer of Respondents (\%) & Yes \\
\cline { 2 - 4 } & $\begin{array}{c}\text { Do you have the plan to manage } \\
\text { and take care of vetiver grass }\end{array}$ & 100 & 100 \\
\hline 2 & $\begin{array}{c}\text { Do you have plan/intention to im- } \\
\text { plement vetiver grass on the rest of } \\
\text { your plots }\end{array}$ & 100 & \multirow{2}{*}{$\begin{array}{c}\text { Do you believe that implementing } \\
\text { SWC technology is the farmers } \\
\text { responsibility }\end{array}$} \\
\hline 3 & $\begin{array}{c}\text { Should the farmers be paid for } \\
\text { implementing and maintaining of } \\
\text { SWC in their farms }\end{array}$ & 70.6 & 29.4 \\
\hline 4 &
\end{tabular}

(Table 5) It is obvious that the end user of agricultural research is large community of farmers and other stake holders. Based on this, the willingness of the farmers to adopt and disseminate vetiver grass technology have also been assessed and all the farmers were willing to implement on the rest of their plot, to take care of the grass and believe implementing different 
soil and water conservation as their responsibility. But,70.6\% of the farmers said the farmers should be paid for implementing and maintaining soil and water conservation which is related with the land policy of our country which says the land belongs to the government where as $29.4 \%$ of them believe the government shouldn't pay for the farmers hence, they till for themselves.

\section{Conclusion}

The result obtained from this study indicates the conservation potential of vetiver grass. Beside this, the study also creates awareness and motivation among farmers about vetiver grass and its importance when supplementing with physical soil and water conservation measures in the area. But the fertility status of deposited soil is decreased because of continuous removal fertile soil layer by water erosion. So, this can be improved by other fertility enhancement methods especially organic fertility improvement measures, because it can be used for both fertility improvement and soil erosion control. Not only that, organic soil fertility enhancement methods are also used to improve the structure/aggregation of soil and increase the permeability of the soil. Thus, the farmers and other stakeholders should have to use and disseminate this miracle grass on their farmlands to reduce the soil loss by using drought, fire and moisture stress resistant grass.

\section{References}

1. Herweg, Stillhardt B (1999) The variability of soil erosion in the Highlands of Ethiopia and Eritrea. Research Report 42. Centre for Development and Environment University of Berne Switzerland.

2. FAO (Food and Agriculture Organization of the United Nations) (1986) High lands reclamation Study -Ethiopia. Final report, Food and Agriculture Organization, Rome 1.

3. Hurni H (1986) Guidelines for development agents on soil conservation in Ethiopia. Soil Conservation Research Project. Community Forests and Soil Conservation Development Department, Ministry of Agriculture Addis Ababa Ethiopia.

4. Nyssen J (1995) Soil erosion in the Tigray Highlands (Ethiopia): I. Natural and human environment in its relationship to soil erosion. Geo-Eco-Trop 19: 51- 82.

5. Babalola 0 (1993) Works of water on Earth. An Inaugural Lecture. University of Ibadan, p. 43.

6. World Bank (1990) Vetiver Grass: The Hedge against Erosion. (3 ${ }^{\text {rd }}$ edn), World Bank, Washington, DC, USA p. 78.

7. Randev HS (1995) Vetiver technology in Nigeria. In: Grimshaw RG, Helfer L (Eds.), Vetiver Grass for Soil and Water Conservation, Land Rehabilitation and Embankment stabilization. World Bank Tech, pp. $145-146$.

8. Assefa Menna, Fekadu Getnet, Tesfaye Midega, Yonas Zeleke (2007) Assessment of Indigenous Soil Conservation Practices/Materials in Metekel Zone. Unpublished.

9. Tessema Chekun ND (2008) Project Proposal On Vetiver Promotion In The Amhara Regional State - Ethiopia.

10. Alemu Mekonnen ND (2008) Report on vetiver Grass Technology Programme. Integrated Food Security Project. Amhara Regional State Ethiopia.

11. Nyssen J, Moeyersons J, Poesen J, Deckers J, Mitiku Haile (2002) The environmental significance of the remobilization of ancient mass movements in the Atbara-Tekeze headwaters, Northern Ethiopia. Geomorphology 49: 303-322.

12. Nigussie Haregeweyn, Poesen J, Nyssen J, Verstraeten G, de Vente J, et al. (2005) Specific sediment yield in Tigray-Northern Ethiopia: Assessment and semi-quantitative modelling. Geomorphology 69: 315-331.

13. Moeyersons J (2001) Deforestation, gully development and desertification in sub-Saharan tropical and subtropical Africa. Poster presented at Second International Conference on Tropical Climatology, Meteorology and Hydrology, Brussels, p. 12-14.

Your next submission with Juniper Publishers will reach you the below assets

- Quality Editorial service

- Swift Peer Review

- Reprints availability

- E-prints Service

- Manuscript Podcast for convenient understanding

- Global attainment for your research

- Manuscript accessibility in different formats

( Pdf, E-pub, Full Text, Audio)

- Unceasing customer service

Track the below URL for one-step submission https://juniperpublishers.com/online-submission.php 